\title{
The Ambiguities of Iconic Design: Mo Modern Art Museum by Daniel Libeskind
}

\author{
Samalavičius Almantas \\ Department of Architectural Fundamentals, Theory and Art, Vilnius Gediminas Technical University, \\ Vilnius, Lithuania
}

Corresponding e-mail: almantsam@yahoo.com

Article info:

Received: 17-05-2019, Revised: 08-07-2019, Accepted: 25-07-2019

\begin{abstract}
The article is focused on the cultural phenomena of architectural iconism that has become globally widespread due to the continuous pressure of ongoing economic, ideological and cultural globalisation and the reigning interests of the web of building industry that appropriates architectural design for its own financial purposes as well as local political stakeholders who often seek to replicate the success of previous internationally renowned iconic buildings by aspiring to the status of worldclass cities. While discussing the global and local cultural contexts in which the so-called 'Bilbao effect' triggered the current pursuit of iconic buildings, the author of the article analyses the much publicized recent example of iconic architecture in Eastern Europe - the MO Modern Art Museum that was designed by Daniel Libeskind and opened in Vilnius, the capital of Lithuania in 2018 on the site of an abandoned and eventually demolished cinema in the vicinity of the historical Old Quarters. It is argued that despite of publicity and largely overcooked praises of international architectural media, the museum's architectural design remains an example of 'signatory architecture' that largely ignores the aesthetics of its local urban environment and peculiarities of local historical and cultural context. It is suggested that that despite of claims of being contextual, in fact the building is not and on the contrary: it exhibits most of the aesthetics features that plaque iconic buildings in various localities on different continents.
\end{abstract}

Keywords: starchitecture, iconic buildings, Daniel Libeskind, aesthetics, Genius Loci.

\section{Introduction}

The MO Modern Art Museum in Vilnius, the capital of Lithuania was opened in 2018 and immediately featured in international media. The building was designed by Daniel Libeskind - an internationally renowned Polish-American contemporary architect who often falls into the category of 'starchitects' and who like other successful international architectural designers are regularly cited and praised by the architectural media. Most of the architectural structures designed by Libeskind as well as other starchitects and are usually labelled as iconic.

Despite of the temperance of the local Lithuanian architects and architectural critics, international media was awed by the structure designed by Libeskind for Vilnius city. Most of the opinions about this newly erected architectural structure disseminated in the international media contained adoration and praise. For example, introducing the recently opened Modern Art Museum to the international audience in the magazine Metropolis architectural critic Sam Lubell not only warmly welcomed the building but also concluded that its design might be considered "successful" from various points of view. (Lubell, 2018)

The tendency of the international media to view the buildings of international starchitects in extremely positive terms is hardly new or surprising. Veneration of the role of the so-called 
'starchitects' responsible for creating an array of iconic buildings in various localities can be traced through the writings of influential contemporary architectural critics like Charles Jencks (Jenck, 2005) or Dejan Sudjic (2005) to mention but a few. It is no surprise that popular media creates cultural discourse exalting the role of some supposedly highly successful architects and promoting iconic buildings for their novelty as well as their contribution to economics (that often takes forms of global tourist flows).. For e. g. the website architecturetravels.com among other things presents the phenomena of starchitecture and iconism as embodiment of the global spirit of our times: "The idea of the 'starchitects' - architects who are globally renowned for their signature style in the design of buildings, has emerged as something of a phenomenon in recent years. It is a term coined to describe the so-called superstar architects whose work has emerged as iconic of its time."

Questionable and often culturally ambiguous results of the present cult of 'starchitect' and architectural iconism have been lately more adequately discussed by such architectural and urban theorists and sociologists as Douglas Murphy (2012), Leslie Sklair (2005, 2018), Nikos Salingaros $(2013,2017)$ or Michael Mehaffy (Salingaros and Mehaffy, 2015) as well as some others. Salingaros and Mehaffy go further the usual critique of iconism and starchitecture questioning the overall legacy of modern movement in architecture that they dismiss as being simplistic, non-adaptive, unsustainable and non-resilient. In addition some researchers have estimated that production of iconic buildings could be also seen as economically profitable for architects themselves as financial value of a particular structure goes higher if it is designed by someone who might be labelled a 'signature architect' or 'starchitect'. (Fuerst, McAllister, C.B. Murray, 2011: 179). Yet though critical voices questioning the image and cultural ambiguities of starchitecture and the global industry of iconic designs have provided ample ground for more adequate analysis of the cultural, aesthetic and psychological results of this global enterprise, the mainstream media often seems to either disregard or simply by-pass any serious criticism of this current architectural and cultural phenomena. Nevertheless, further critical elaboration on iconic buildings and especially their cultural consequences is urgent, moreover so that these types of buildings continue to proliferate all over the globe and their favourable media coverage and supposed economic success prompts local commercially-minded architects to imitate their roles even when results that are more questionable than the objects of their inspiration (Heathcote, 2017).

Thus the aim of this article is to analyse the cultural consequences of starchitecture and iconism by focusing on one of the recent examples of this kind of architecture: MO Modern Art Museum designed by Daniel Libeskind. Providing its critical appraisal the author attempts to demonstrate that despite endorsements in the international architectural media its aesthetics ignores and by-passes its cultural and architectural context.

\section{Method}

The author of the present article employs a combination of several qualitative methods, blending together critical analysis, architectural phenomenology and last but not least iconological approach once introduced by Erwin Panofsky for the study of visual media. This kind of complex approach focuses on the meanings of the visual objects and also involves a reflection on the subjective personal reactions to the visual phenomena. My interpretation and analysis of the building and its environment is based on the concept of genius loci (or spirit of place) elaborated by architectural phenomenologist Christian Norberg-Schulz and understanding of architectural experience as tactility rather than ocular scenography as argued by Kenneth Frampton. In addition to this kind of understanding of architectural experience I also approach architecture as cultural signs reflecting current ruling ideologies and embodying the meanings created by dominating global cultural discourses. 


\section{Result and Discussion}

\subsection{An Overview of the Idea of Designing an Iconic Museum in Vilnius}

Inspired and captivated by the by the phenomenon of the so-called McGuggenization (McNeil, 2000), municipal politicians in a vast number of European and non-European countries had been looking forward for some culturally impressive, visually spectacular and sociologically iconic buildings to be designed by international architectural celebrities since the success story of Guggenheim Bilbao was reported more than two decades ago. As a consequence, a phenomenon known as "Bilbao effect" triggered by the museum designed by postmodernist American architect Frank O. Gehry for an industrial city of Bilbao (the Basque country, Spain) came into being. According to its narrative, the industrial city of Bilbao was experiencing economic and social problems and iconic museum contributed decisively to the revival of its economy. Opened in 1997 Gehry's Bilbao immediately set an example for numerous municipal politicians in different parts of the world, especially to those who like then Vilnius's mayor Artūras Zuokas aspired to make their cities 'world-class'. Cultural institutions like museums and galleries seemed to be most suitable objects for attracting both media and popular attention as well as accumulating financial revenue after becoming sites for global cultural tourist consumption. (Trilupaitytè 2009).

During the period of 2000-2007 when Zuokas served as the mayor of Lithuania's capital, New York Guggenheim Museum managed by Thomas Krens was rapidly expanding its branches in different locations of Europe and Asia. The success and international reputation of Guggenheim Museum in Bilbao inspired municipal leaders in Vilnius to stage an international contest for another Guggenheim. Three well-known international starchitects Zaha Hadid, Massimiliano Fuksas and Daniel Libeskind responded to the call and took part in the international competition that was finally won by Zaha Hadid.

However, the project of Guggenheim Museum in Vilnius did not finally materialize despite promising results of the design competition with international 'starchitects' of highest calibre. After the prize-winning project was announced, a wave of disillusionment and public debates questioning the results of this competition followed. In addition, Lithuanian architectural community remained hostile to the project. To make things worse, the funds for would-be building were not accumulated as the two main stakeholders in the so-called 'Guggenheimaffair' - Thomas Krens and Artūras Zuokas lost their respective offices even before final results were announced. Tomas Krens - director of Guggenheim's international network was forced to resign as the governing board of trustees was annoyed by alarmingly rapid expansion of its branches in different places outside USA at the expense of its main New York headquarters. Meanwhile Artūras Zuokas - the main local driver of this project in Lithuania lost municipal elections to his successor who turned out to be less enthusiastic about the project.

After a few years, however, the idea of establishing a museum of modern art in Lithuania's capital was revived in a different form. A couple of art collectors came up with an idea of a private museum of modern art to be established in Vilnius. The idea won more public support than Guggenheim because it suggested the establishment of an art museum exhibiting a collection of national art rather than funding a branch of an international 'chain-gallery' importing foreign art exhibitions to the local audience. 


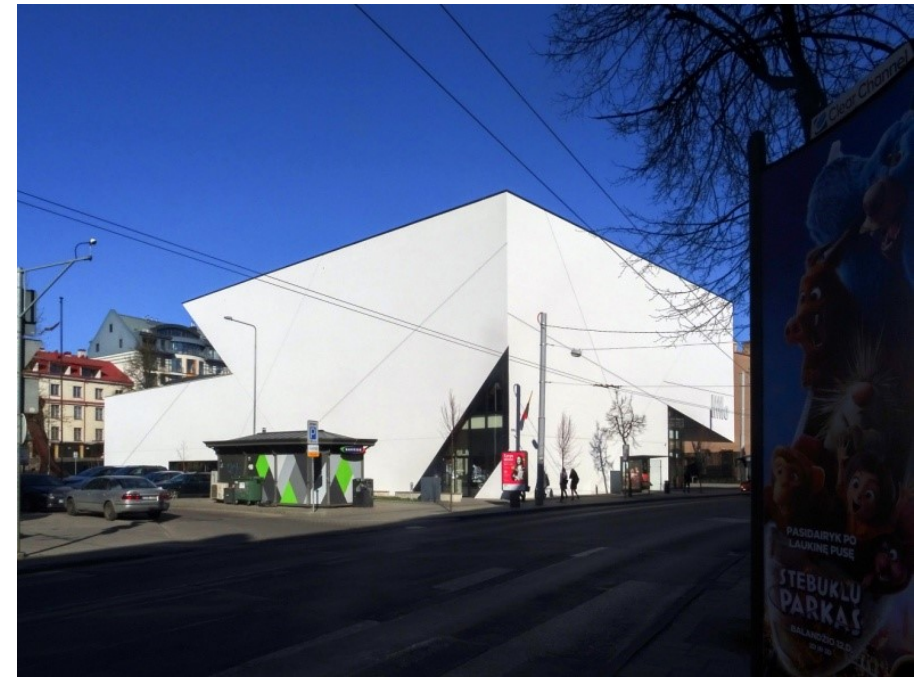

Figure 3.1. MO Museum designed by Libeskind (author's photo 2018)

Daniel Libeskind was immediately chosen by the donors as architectural designer. This time no competition was needed as museum project was privately funded. Thus Libeskind was eventually offered a contract to design a museum building in a different location than the original Guggenheim Museum in Vilnius was supposed to be situated. The vicinity of the historical Old Quarters of Vilnius containing a popular cinema 'Lietuva' of the Soviet-era abandoned in post-Soviet period was chosen as a site for MO Modern Art Museum. The cinema building was eventually demolished and a new architectural structure designed by Daniel Libeskind opened to public in 2018 and was immediately endorsed by international architectural media as being both 'brave' and 'contextual'.

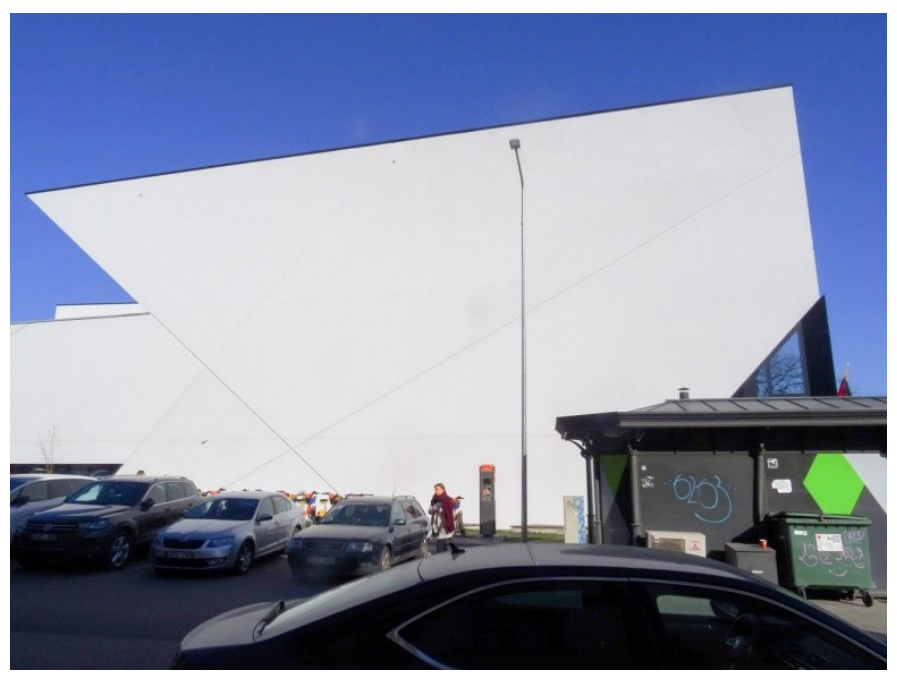

Figure 3.2 Side façade as blind curtain wall (author's photo 2018)

\subsection{Aesthetic Appraisal of MO Modern Art Museum}

Some architectural critics discussing the Modern Art Museum in international media conclude that "the museum is without a doubt a success - an electrifying and inviting game changer for a place that certainly needs one. With its stirring embrace of its surroundings and its 
elegant, but not precious, relationship to art and space, it provides valuable lessons for an art world that tends to take itself too seriously and turn its back to those outside its cloistered confines." (Lubell, 2018). Despite of the fact that the building seems to perform its function of a museum neither better nor worse than many other contemporary buildings of this kind, its aesthetic qualities demand a closer scrutiny.

First comes the issue of contextuality. Most architectural objects designed by starchitects essentially aim to imprint a recognisable signature on the surrounding urban milieu rather than to establish and maintain a spatial and aesthetic 'dialogue' with the older local historical buildings in their immediate architectural environment. Though the designer of Mo Modern Art Museum insisted that while designing his building he cared about its historical environment and some architectural critics have described the building as 'contextual' (Lubell), its is difficult to find any evidence of its supposedly contextual character while experiencing the building on site. Though philosopher Roger Scruton rightly argues that architecture is among other things 'an art of ensemble' and 'all serious architecture aims at an effect of unity' (Scruton, 1979: 11), like many other modernist structures Libeskind's building exhibits no traces of being related in any way to its architectural environment, except perhaps its unusually moderate size. But in fact limits to size were set by Lithuania's state legislation regulating how high the buildings can be in the protection zone of the Old Quarters.

Moreover, the buildings around the museum are mostly historical, having been built in the eighteenth-nineteenth centuries following the Neo-Classical style. For e.g. the building of the Architectural School of Vilnius Technical University situated just across the street in front of museum's main façade is a historical urban manor house, designed in the eighteenth century for a local family of nobles and though it experienced several refurbishments, its present façade represents the architectural aesthetics on Neo-Classicism. Meanwhile Mo Modern Art Museum is designed as a large white explicitly modernist box diagonally cut into two parts by the stairs installed in the middle of the structure. Thought the inscription in the official website of Libeskind's studio suggests that the building was plastered in accordance with other traditional buildings of the Old Quarters, neither plaster covering the concrete blocks, nor white colour is able to appeal to senses or to connect it meaningfully to its surroundings.

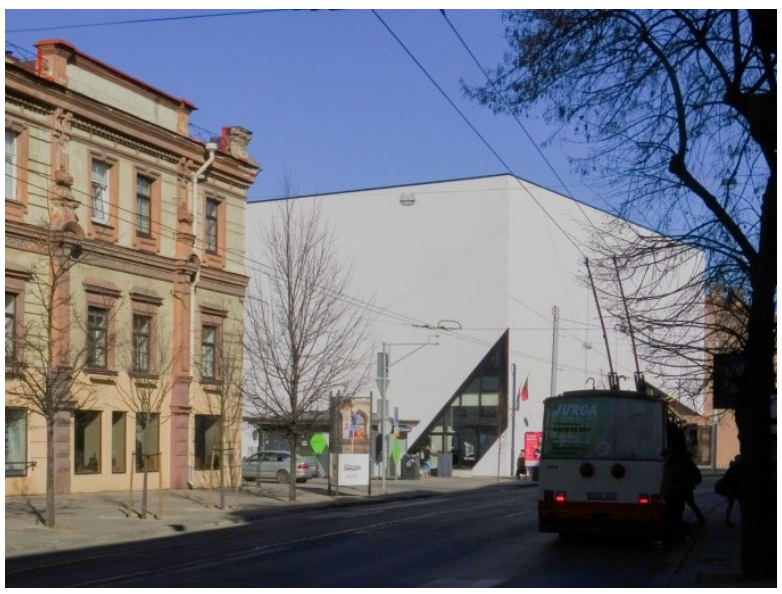

Figure 3.3 Museum and its environment (author;s photo, 2018)

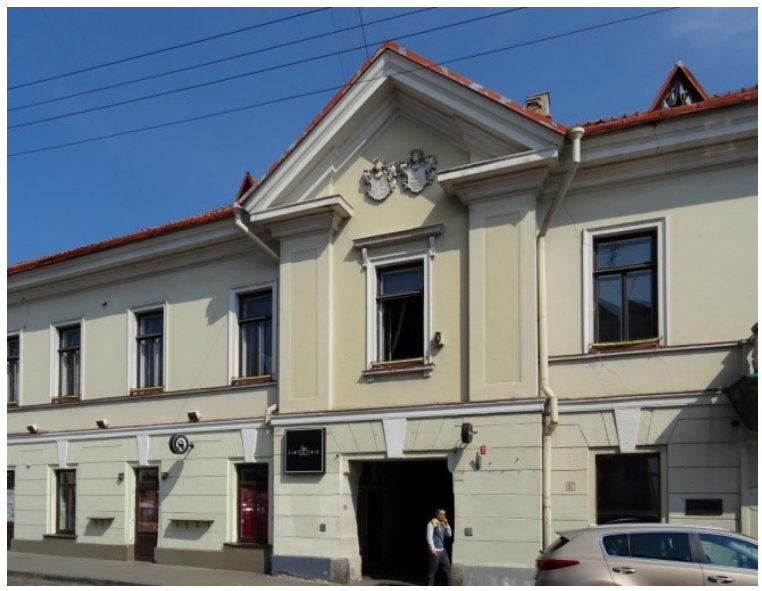

Figure 3.4. Umiastovskiai palace in the vicinity of museum (author's

From a formal point of view museum's exterior arrangement is equally unsatisfactory and disappointing sight: its shed-like forms are non-imaginative and surprisingly un-iconic, moreover, irregularly shaped both side facades act as impenetrable large flat screens blocking the close-up views because of the lack of surrounding public space that usually is 
used to look at the buildings of this type. Like most modern buildings designed according to prescription of Le Corbusier, the blind walls of the museum are devoid of any architectural decoration and only have a couple of small, irregularly cut windows and consequently, its boxy visual appearance does not in any way resonate with the facades of the surrounding historical buildings that contain rhythmically displayed windows with modest, yet tasteful decorations peculiar to pre-Modern architecture when ornament was not yet famously described as crime by Adolf Loos.

The choice of monochromic design is also highly questionable as it only visually emphasizes the building's square shape. Plastered walls of the museum are painted in sterile white colour that will inevitably become greyish in the very near future because of the climate. Besides white colour is rather exception that rule in the decoration of this area as majority of historical buildings in the Old Quarters of Vilnius are mostly painted in yellowish, red or brown colours. The use of white colour is far less typical for this as well as the other historical parts of Vilnius, and on the other hand, it immediately invokes associations with another local iconic modernist building of CAC (Contemporary Art Center) designed and erected by Lithuanian architect Eduardas Cekanauskas in post-WWII era. Both structure, coincidentally are not friendly to their historical environment. In addition, screen-like, flat and almost completely blind walls of the MO Modern Art Museum provide no feeling of the material's texture as white plaster - supposedly used for the sake of minimalism does not leave any room for sensual experience of the structure except being offered as a piece of odd scenography..

\subsection{Form and Function}

Mo Modern Art Museum might also be viewed as embodying a certain confusion in functional terms that are generally peculiar to the structures influenced by the ideology and aesthetics of architectural modernism. There are several aspects of this kind of ambiguity or even controversy. Though the very purpose of building - to serve as a space for exhibiting art works presuppose very precise functions, the present structure in this sense remains quite ambivalent. Surprisingly, the interior space does not contain a lobby that one expects to find in a structure designed to be a museum. More than that, some other important functional elements turn out to have been constructed for exclusively aesthetic purposes rather than functional reasons, like for e. $g$, the stairs on the facade that lead inside to the upper floor of the building that is designed as an outdoor space with an array of steps leading upwards. As almost invisible entrance (this for a strange reason is quite typical for many contemporary edifices that function as museums or art galleries) is located on the ground floor the function of the stairs is merely illusionary and/or complimentary. When one climbs up one finds himself on a small open-air platform with a row of steps leading further to the top that are devoid of exact function. Meanwhile the leaning wall on one of its sides creates a feeling of insecurity. 


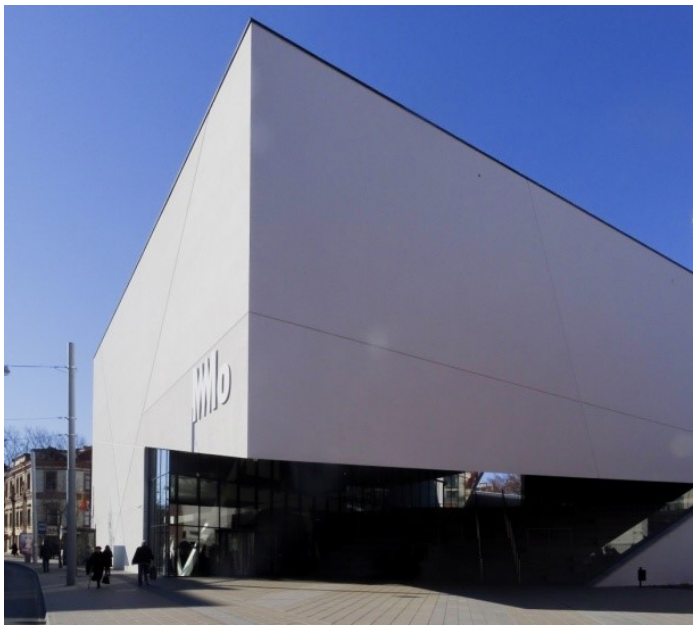

Figure 3.5. The frontal view with the steps (author's photo, 2018)

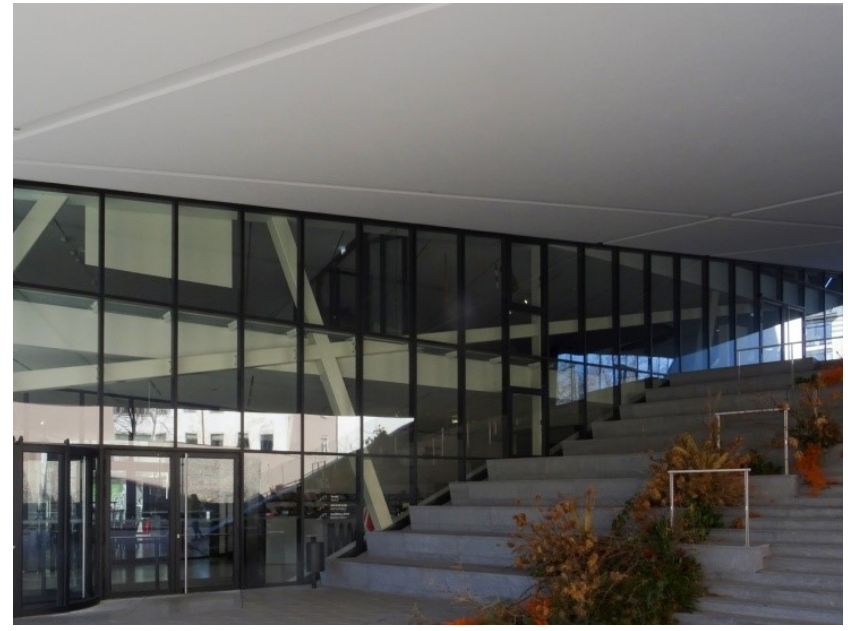

Figure. 3.6. The steps and the entrance (author's photo, 2018)

This exterior open space might be possibly used either for some public open air events (lectures or meetings) or for looking around at the surroundings, but if this was the intention of its designer, there are at least two problems involved. As the building is located in a country where the weather during most part of the year is cold and rainy rather than sunny and warm, it can only be used for outdoor events just for a few summer months. If it was intended to provide an open-air platform for sight-seeing, it might be argued that the availability of sights around is very limited and because of the peculiarities of the flat site, there is almost no space for any panoramic views as the sights from the open space of the museum's building are cut by the vertical rise of the building's leaning wall and other visual obstacles, like the hill on the back side of the building packed with unimpressive modernist structures.

\subsection{Cognitive Aspects}

As Nikos Salingaros has emphasized, it is "biophilia" that determines our relation to the environment (Salingaros, 2017: 163). Our experience of architectural structures is both sensory and intellectual, employing sensorial and intellectual capacities we react to any visible and tangible objects in our environment either consciously or most often often subconsciously. Moreover, as Christopher Alexander has convincingly demonstrated, geometrical configurations correspond and react to human bodies (Alexander, 1977). For numerous reasons humans need to grasp and comprehend their environments, say, in order to reach their destination while moving or to feel safe and confident in their natural or urban milieu. However, as Malcolm Millais has demonstrated (Millais, 2009) many modern iconic buildings designed by starchitects simply ignore this biologically conditioned human need as they are designed and localized in particular urban spaces for completely different purposes: they are only meant to act as signifiers of a certain architectural brand, to reinforce starchitect's reputation in a particular locality and make the place more attractive for potential tourism and/or expansion of business and commerce. Thus architectural designers often choose certain forms and aesthetic expression that is meant to stand out, to excite and alert rather than to bring or add any unity and harmonious interaction between buildings in particular urban area.

It is proved both by cognitive research and evidence that "An abstract design that looked fine in a rendering, but which failed to evaluate - and adjust for - all predictable human sensory reactions could turn out to be a threatening and oppressive environment when built". (Salingaros, 2017). People usually avoid large protruding parts of the building or walls that have an illusion of falling down. Libeskind' Mo Modern Art Museum largely ignores these 
findings of cognitive research. While approaching the building from its sides a viewer can only face large and almost blind impenetrable white screens (walls) that are boringly flat and devoid of texture and material qualities. Small irregular-shaped windows do not help to discard the illusion of this building as a closed boxy structure that does not resonate with its architectural environment. Moreover, when one approaches the stairs visually cutting the building in two from its frontal façade, one can hardly escape the feeling that the wall is obliquely descending right upon your head and it is proved by experimental research that humans feel awkward and unsafe in such built environment (Alexander, 1977). Thus it can be argued that the design of museum and its optical effects largely ignore our biological bodily capacities to grasp the environment and to respond to it - what is known in cognitive terms as prehension. The oppressive forms of the museum's building indicate that not much consideration was given to human senses except the eight and attention was only paid to strengthening some optical effects that alert and excite human reactions rather than taking into consideration how visitor's body and senses respond to psychologically aggressive, rude and dominating forms of this architectural structure that aims to imprint a recognisable signature upon a viewer rather than to please our minds and emotions.

\section{Conclusion}

It can be concluded that despite of the claims of its author and architectural critics that his building was designed taking into consideration the historical environment of the Old Quarters of Vilnius, it is not proved by any evidence, since MO Modern Art Museum in Vilnius chooses to ignore its surroundings.

The building exhibits a number of features peculiar to iconic architecture produced by 'starchitects' in very different geographical and cultural localities. First of all it undermines and ignores the history of the site and its spirit of place (genius loci), as this modernist boxy structure rather contrasts with other buildings than adapts to its architectural and natural environment. Instead of establishing a spatial dialogue and harmonious co-existence with other architectural structures and natural environment it only enhances its own singularity and exceptionality. As such it remains a recognisable signature architecture rather than being anything else.

Prescriptive claims to experience Libeskind's building as contextual are equally ambiguous as in fact it is anti-contextual like most examples of iconic signatory architecture that intend to impose a recognizable individuality of a starchitect on the environment rather than establish meaningful connections with its urban surroundings. Instead of modestly contributing to the atmosphere of the place created by surrounding historical buildings throughout centuries, it works against them. As such it can be viewed as externalizing a spirit of global cultural commodification and the triumph of global market capitalism that is indifferent to such subtleties as historical heritage or the spirit of a particular urban place.

\section{References}

Alexander. C, et at al. (1977) A Pattern Language. New York: Oxford University Press.

Frampton, K. (2005). The work of architecture in the age of commodification. Harvard Design Magazine, 23, 1-5.

Fuerst, F., McAllister, P., Murray, C.B. (2011). Designer buildings: estimating the economic value of 'signature' architecture. Environment and Planning , 43, 166-184. Doi:1068/a43270.

Jencks, C. (2005). The Iconic Building: The Power of Enigma. London: Frances Lincoln.

Heathcote, E. (2017). Age of 'starchitect'. Financial Times, https://www.ft.com/content/d064d57c-df01-11e6-86ac-f253db7791c6. 
McNeil, D. (2000). McGuggenisation? National identity and globalisation in the basque country, 19 (4), 473-494.

Millais, M. (2009) Exploding the Myths of Modern Architecture. London: Frances Lioncoln.

Murphy, D. (2012) The Failure of Architecture. Winchester and Washington: Zero Books,

Lubell, S. (2018) Studio Libeskind designs a bold yet contextual new art museum for Vilnius (15 November 2018). https://www.metropolismag.com/architecture/studio-libeskindvilnius-mo-museum/

Ponzini D. (2014). The values of starchitecture: commodification of architectural design in contemporary cities. Organisational Aesthetics. 3 (1), 10-18.

Salingaros N. A., Mehaffy M. (2015). Design for a Living Planet. Portland: Sustasis.

Salingaros. N. A., Samalavičius A. (2013). Revisiting and rethinking contemporary urban design, Journal of Architecture and Urbanism, 37 (3), 161-164.

Salingaros N.A. (2017) Why do we need to "grasp" our surroundings: object affordance and prehension in architecture, Journal of Architecture and Urbanism, 41 (3), doi: 10.3846/20297955.2017.1376003.

Salingaros N. A. (2017). Design Patterns and Living Architecture. Portland: Sustasis.

Samalavičius, A. ed. (2017). Rethinking Modernism and the Built Environment. Newcastle upon Tyne: Cambridge Scholars Publishing.

Scruton, R. (1979) The Aesthetics of Architecture. Princeton: Princeton University Press.

Sklair, L. (2006). Do cities need architectural icons? Urban Studies, 43 (10), 1899-1918.

Sklair. L. (2017). The Icon Project: Architecture, Cities and capitalist Globalisation. Oxford: Oxford University Press.

Sudjic, D. (2005). How the Rich and Powerful Shape the World. London and New York: Allen Lane.

Trilupaityte, S. (2009). Guggenheim's global travel and the appropriation of a national avantgarde for cultural planning in Vilnius. International Journal of Cultural policy, 15 (1), 123-138. 